
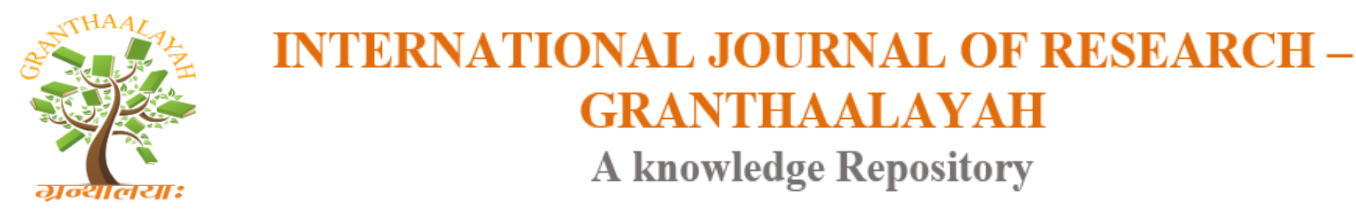

Management

\title{
DETERMINANTS OF PRIORITY SECTOR LENDING OF INDIAN PUBLIC SECTOR BANKS: AN ECONOMETRIC ANALYSIS
}

\author{
Santosh Kumar Panda ${ }^{* 1}$, Ganesh Prasad Panda ${ }^{2}$, Dr. Anil Kumar Swain ${ }^{3}$ \\ ${ }^{* 1}$ M.Com, ICWA (Inter), MBA, M.Phil, Lecturer in Costing, Government College of \\ Engineering, Keonjhar, Odisha - 758002, India \\ 2 M.Com, M.Phil, UGC JRF/ NET, Lecturer in Commerce, Sadhu Goureswar College, \\ Kanikapada, Jajpur, Odisha - 755011, India \\ ${ }^{3}$ Associate Professor in Commerce, Head, PG Department of Commerce, Utkal University, \\ Vanivihar, Bhubaneswar, Odisha - 751004, India
}

\begin{abstract}
Compulsory sanctioning credit or priority sector lending (PSL) is part of the regulatory framework for commercial banks/ financial institutions in many countries, both developing and developed. However, compliance and lending effectiveness of such programs may be determined by a number of factors. This may be particularly so in developing countries, where availability of finance for the vulnerable sectors likes agriculture, small businesses, weaker sections, are scarce. The present paper aims at examining the patterns of priority sector lending by banks, with a view to identifying the factors which determine this lending The paper is based on an analysis of secondary data relating to priority sector lending (2006-07-2015-16) for the Public sector banks in India. The results indicate gaps in patterns of the sect oral target compliance by different bank groups, along with the lending preferences and challenges faced by banks in such lending. It also identifies bank-specific characteristics like the nature of ownership, size, performance, etc., which have a significant impact on the priority sector lending patterns. Based on its findings, the paper offers policy suggestions for improving the effectiveness of priority sector lending program.
\end{abstract}

Keywords: Priority Sector Lending; Financial Institutions; Agriculture; Public Sector Banks; Lending Preference.

Cite This Article: Santosh Kumar Panda, Ganesh Prasad Panda, and Dr. Anil Kumar Swain. (2017). "DETERMINANTS OF PRIORITY SECTOR LENDING OF INDIAN PUBLIC SECTOR BANKS: AN ECONOMETRIC ANALYSIS." International Journal of Research Granthaalayah, 5(7), 461-473. https://doi.org/10.29121/granthaalayah.v5.i7.2017.2154.

\section{Introduction}

An enunciation of the need to channelize the flow of credit to certain sectors of the economy, known as the priority sectors, in the larger interests of the country, can be traced to the Reserve 
Bank's credit policy for the year 1967-68. In view of the severe imbalances which had developed in the economy in the preceding two years as a result of shortfalls in agricultural output and slowing down of industrial production, credit policy for the slack season 1967 was liberalized on a selective basis with a view, among other purposes, to enlarging the flow of credit to the priority sectors such as agriculture, exports and small-scale industries (SSI). Social control over banks

At around the same period, the Government of India initiated steps to institute social control over banks to remove certain deficiencies observed in the functioning of the banking system and to promote a purposive distribution of credit, consistent with the basic economic and social objectives. One of the deficiencies observed was that traditionally, the bulk of bank advances was directed to large and medium-scale industries, and big and established business houses, while agriculture, SSI and exports - the hitherto neglected sectors - did not receive adequate attention. The measures for social control over banks, were therefore, initiated by the Government of India in 1967-68 with a view to securing a better adaptation of the banking system to the needs of economic planning and its playing a more active and positive role in aiding sectors like agriculture and SSI. The scheme of social control envisaged a purposive distribution of available lendable resources as well as a more effective mobilization of savings.

\section{Review of Literature}

Berger and Black (2010) go on to say that while the smaller banks have a comparative advantage in lending based on relationship or soft basis, but this could also include "judgment" lending. Herein, judgment of the lending officer based upon his experience and training, is used to assess and extend loans. Berger and Udell (2006) in their study assess the issue of credit availability to small and medium enterprises (SMEs) in a holistic manner, rather than in a narrow sense. Lending technologies, as defined in terms of procuring information, screening them, structuring loan contracts and monitoring mechanisms, are viewed as a conduit to enable varying government policies and financial structures to translate to credit availability to SMEs. The study underlines the importance of considering not only bank size, but also its nature of ownership and the lending environment to explain their varying lending technologies, and hence credit availability to smaller firms

Kumar and Francisco (2005) found that smaller firms have more difficulty in credit access and have more credit constraints, and state-owned banks are more likely to lend to larger firms. Thus, government intervention in ownership of banks may not be very favorable for lending to small and information ally opaque firms.

Banerjee and Duflo $(\mathbf{2 0 0 4}, \mathbf{2 0 1 4})$ found that the small firms are credit constrained, and that the banks also find such lending profitable. In spite of this, banks are reluctant to increase the amount of lending and especially to new firms, mainly to avoid possible action against them for bad decisions (good performance anyway does not attract enough rewards). This may as well be peculiar to public sector banks.

Wilson, Kastens, and Jones (2007), in their study explored the lender and borrower specific factors which impact bank lending to agriculture. Among other things, borrower's character, and his credit risk or the expected probability of default, were found to be significant factors impacting the loan amount. Loan officer characteristics, in terms of percent of time lenders spent 
on agricultural loans and number of years' experience as an agricultural loan officer, were also found to be significant.

Mohan (2006) puts into perspective, the need to lend beyond traditional avenues, given the changes in demand and supply pattern of agricultural products. Not just production, financing of other affiliated activities like diversification, value added (processing) services, technology, inputs, marketing, distribution and rural infrastructure are also important for agricultural lending objectives to succeed.

Guha (2009), which aimed to see if agricultural and SSI lending by banks is influenced by political motives. It was found that credit to these sectors rose before and during general election years and thus, had political cycles.

\section{Objectives of the Study}

i. To make a conceptual study of Priority Sector lending pattern in India

ii. To examine the impact of various determinants on PSL of Indian Public sector banks.

iii. To suggest some ideas for effectiveness of PSL programmes among Indian banks.

\section{Research Hypotheses}

H1 There is a positive and significant relationship between PSL and bank size

H1 There is a positive and significant relationship between PSL and Bank Performance

H1 There is a positive and significant relationship between PSL and Lending efficiency.

\section{Research Methodology}

\subsection{Sources of the Data}

The data are basically collected from secondary sources. This secondary source includes mainly Reports on Trends and progress of banking in India from the RBI website. The statistical tables are prepared by compiling data from RBI publications and statistical tables. Besides that I have borrowed a lot of things from various Magazines \& journals. Many websites have also been referred for collecting much important information. Various articles and research papers form internet also have been used for gathering a lot of information to prepare this dissertation.

\subsection{Period of the Study}

The period for the study covered 10 years from 2006-07 to 2015-16 and the essential data have been collected for all the Public sector banks in India.

\subsection{Econometric Modelling}

In order to understand the impact of determinants like Bank size, Bank performance and Lending efficiency on Priority sector lending, an empirical exercise is being carried out by taking panel data for Public sector banks in India from the period 2006-07 to 2015-16 in a multiple linear regression framework. 
- Bank size consists of the variables like Deposits, advances and Employee strength.

- Bank performance consists of the variables like CAR, ROA and NIM.

- Lending efficiency consists of the variables like C/D Ratio and Gross NPA to total assets Ratio

The Econometrics Model is written as follows:

$Y=\beta 0+\beta 1 \times 1+\beta 2 \times 2+\beta 3 \times 3+\beta 4 \times 4+\beta 5 \times 5+\beta 6 \times 6+\beta 7 \times 7+\beta 8 \times 8+\beta 9 \times 9+\beta 4 \times 4 \ldots \ldots . .+\varepsilon i t$

$\mathrm{Y}=$ Dependent variable $=\mathrm{PSL}$

$\beta 0=$ Intercept term

$\beta 1=$ Co-efficient of Deposits

$\beta 2=$ Co-efficient of advances

$\beta 3=$ Co-efficient of Employee strength

$\beta 4=$ Co-efficient of CAR

$\beta 5=$ Co-efficient of ROA

$\beta 6=$ Co-efficient of NIM

$\beta 7=$ Co-efficient of C/D Ratio

$\beta 8=$ Co-efficient of GNPA to Assets Ratio

$\mathrm{x} 1, \mathrm{x} 2, \mathrm{x} 3, \mathrm{X} 4 \ldots \ldots=\mathrm{independent}$ variables

\section{Categories Under Priority Sector}

- Agriculture

- Micro and Small Enterprises

- Education Loans

- Housing Loans

- Others

\subsection{Targets and Sub-Targets for Banks Under Priority Sector}

\begin{tabular}{|c|c|c|}
\hline Categories & $\begin{array}{l}\text { Domestic scheduled commercial banks and Foreign banks } \\
\text { with } 20 \text { branches and above }\end{array}$ & \begin{tabular}{|l} 
Foreign banks with \\
less than 20 branches
\end{tabular} \\
\hline $\begin{array}{l}\text { Total } \\
\text { Priority } \\
\text { Sector }\end{array}$ & $\begin{array}{l}40 \text { percent of Adjusted Net Bank Credit or Credit Equivalent } \\
\text { Amount of Off-Balance Sheet Exposure, whichever is higher. } \\
\text { Foreign banks with } 20 \text { branches and above have to achieve } \\
\text { the Total Priority Sector Target within a maximum period of } \\
\text { five years starting from April } 1,2013 \text { and ending on March } \\
31,2018 \text { as per the action plans submitted by them and } \\
\text { approved by RBI. }\end{array}$ & $\begin{array}{l}40 \text { percent of Adjusted } \\
\text { Net Bank Credit or } \\
\text { Credit Equivalent } \\
\text { Amount of Off- } \\
\text { Balance } \\
\text { Exposure, whichever is } \\
\text { higher; to be achieved } \\
\text { in a phased manner by } \\
\text { 2020. }\end{array}$ \\
\hline Agriculture & $\begin{array}{l}18 \text { percent of ANBC or Credit Equivalent Amount of Off- } \\
\text { Balance Sheet Exposure, whichever is higher. } \\
\text { Within the } 18 \text { percent target for agriculture, a target of } 8 \\
\text { percent of ANBC or Credit Equivalent Amount of Off- }\end{array}$ & Not applicable \\
\hline
\end{tabular}




\begin{tabular}{|l|l|l|}
\hline & $\begin{array}{l}\text { Balance Sheet Exposure, whichever is higher is prescribed for } \\
\text { Small and Marginal Farmers, to be achieved in a phased } \\
\text { manner i.e., 7 per cent by March 2016 and 8 per cent by } \\
\text { March 2017. } \\
\text { Foreign banks with } 20 \text { branches and above have to achieve } \\
\text { the Agriculture Target within a maximum period of five years } \\
\text { starting from April 1, 2013 and ending on March 31, 2018 as } \\
\text { per the action plans submitted by them and approved by RBI. } \\
\text { The sub-target for Small and Marginal farmers would be } \\
\text { made applicable post 2018 after a review in 2017. }\end{array}$ \\
\hline $\begin{array}{l}\text { Micro } \\
\text { Enterprises }\end{array}$ & $\begin{array}{l}\text { B.5ercent of ANBC or Credit Equivalent Amount of Off- } \\
\text { Balance Sheet Exposure, whichever is higher to be achieved } \\
\text { in a phased manner i.e. 7 per cent by March 2016 and 7.5 } \\
\text { per cent by March 2017. } \\
\text { The sub-target for Micro Enterprises for foreign banks with } \\
\text { 20 branches and above would be made applicable post 2018 } \\
\text { after a review in 2017. }\end{array}$ \\
\hline $\begin{array}{l}\text { Advances to } \\
\text { Weaker } \\
\text { Sections }\end{array}$ & $\begin{array}{l}\text { Bercent of ANBC or Credit Equivalent Amount of Off- } \\
\text { Balance Sheet Exposure, whichever is higher. } \\
\text { Foreign banks with } 20 \text { branches and above have to achieve } \\
\text { the Weaker Sections Target within a maximum period of five } \\
\text { years starting from April 1, 2013 and ending on March 31, } \\
\text { 2018 as per the action plans submitted by them and approved } \\
\text { by RBI. }\end{array}$ \\
\hline
\end{tabular}

\section{Note}

i. Banks should not deduct / net any amount like provisions, accrued interest, etc, from ANBC.

ii. With effect from the fortnight beginning August 24, 2013, incremental FCNR (B) deposits as also NRE deposits with reference to base date of July 26, 2013, and having maturity of three years and above, mobilized by banks, will be exempted from the maintenance of CRR / SLR. Advances granted in India against the incremental FCNR (B) / NRE deposits qualifying for exemption from CRR / SLR requirements, as detailed above, will also be excluded from Adjusted Net Bank Credit for computation of priority sector targets.

\section{PSL Lending by Public Sector Banks (PSBS)}

The outstanding priority sector advances of PSBs increased by 21 per cent in 2003-04 as against an increase of 18.6 per cent during 2002-03. During the period 1995-2004, the average annual growth rate of advances to priority sector by public sector banks was 17.6 per cent as compared to average growth rate of NBC at 16.7 per cent in the same period. The higher growth in priority sector advances of PSBs during the above period was primarily due to 28.8 per cent average growth rate recorded by other priority sectors which compensated for the low average growth rate in credit to SSI (9.3 per cent) and direct agriculture credit (15.7 per cent). The share of priority sector advances in NBC of PSBs increased to 44 per cent in 2003-04 from 42.5 per cent in 2002-03. The growth in priority sector advances of PSBs was fuelled by the surge in the loans 
and advances to various other priority sectors and robust growth of credit to the agriculture sector.

Advances to agriculture constituted 15.4 per cent of NBC of PSBs as on the last reporting Friday of March 2003 (Annexure 6). The share of advances to other priority sectors in NBC of PSBs increased to 17.0 per cent in 2003-04 from 15.0 per cent in 2002-03. The number of accounts covered under various major segments (agriculture, SSI and other priority sectors) of priority sector declined over the period.

Table 1: Outstanding credit to priority sector lendings by PSBs Rs. In Crores

\begin{tabular}{|l|l|l|}
\hline Year & PSB & As \% of ANBC \\
\hline 2001 & $1,46,546$ & 43 \\
\hline 2002 & $1,71,185$ & 43.1 \\
\hline 2003 & $2,03,095$ & 42.5 \\
\hline 2004 & $2,45,672$ & 44 \\
\hline 2005 & $3,10,093$ & 43.2 \\
\hline 2006 & $4,10,379$ & 40.3 \\
\hline 2007 & $5,21,180$ & 39.6 \\
\hline 2008 & $6,08,963$ & 44.6 \\
\hline 2009 & $7,19,497$ & 42.5 \\
\hline 2010 & $8,64,562$ & 41.7 \\
\hline 2011 & $10,28,615$ & 41.3 \\
\hline 2012 & $11,29,990$ & 37.4 \\
\hline 2013 & $12,84,880$ & 36.4 \\
\hline 2014 & $16,18,971$ & 39.4 \\
\hline
\end{tabular}

Source: RBI, Reports on trends and progress on banking in India,

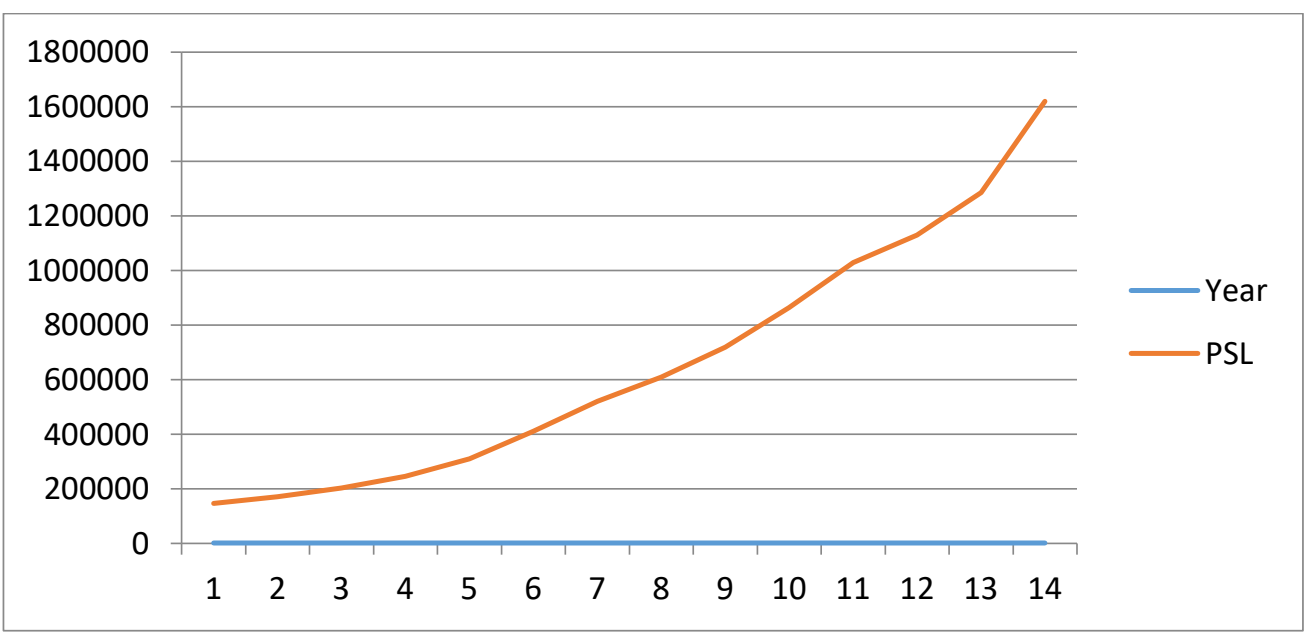

Chart 1: Outstanding credit to priority sector lending by PSBs Rs. In Crores 
Table 2: Total agricultural credit by PSBs in India. (Rs. In Crores)

\begin{tabular}{|l|l|l|}
\hline Year & PSB & As \% of ANBC \\
\hline 2001 & 53685 & 15.7 \\
\hline 2002 & 63082 & 15.9 \\
\hline 2003 & 73507 & 15.4 \\
\hline 2004 & 86186 & 15.4 \\
\hline 2005 & 112474 & 15.7 \\
\hline 2006 & 154900 & 15.2 \\
\hline 2007 & 205090 & 15.6 \\
\hline 2008 & 248685 & 18.2 \\
\hline 2009 & 296856 & 17.5 \\
\hline 2010 & 370729 & 17.9 \\
\hline 2011 & 414990 & 16.6 \\
\hline 2012 & 475148 & 15.7 \\
\hline 2013 & 532801 & 15.1 \\
\hline 2014 & 687242 & 16.7 \\
\hline
\end{tabular}

Source: RBI, Reports on trends and progress on banking in India,

The Government of India initiated measures for social control over banks in 1967-68 with a view to securing a better adaptation of the banking system to the needs of economic planning and its playing a more active and positive role in aiding sectors like agriculture and small scale industries (SSI). One of the objectives of nationalisation of banks was to ensure that no viable productive endeavour should falter for lack of credit support, irrespective of the fact whether the borrower was big or small. Thus, the concept of priority sector lending was evolved further to ensure that assistance from the banking system flowed in an increasing manner to the vital sectors of the economy and according to national priorities.

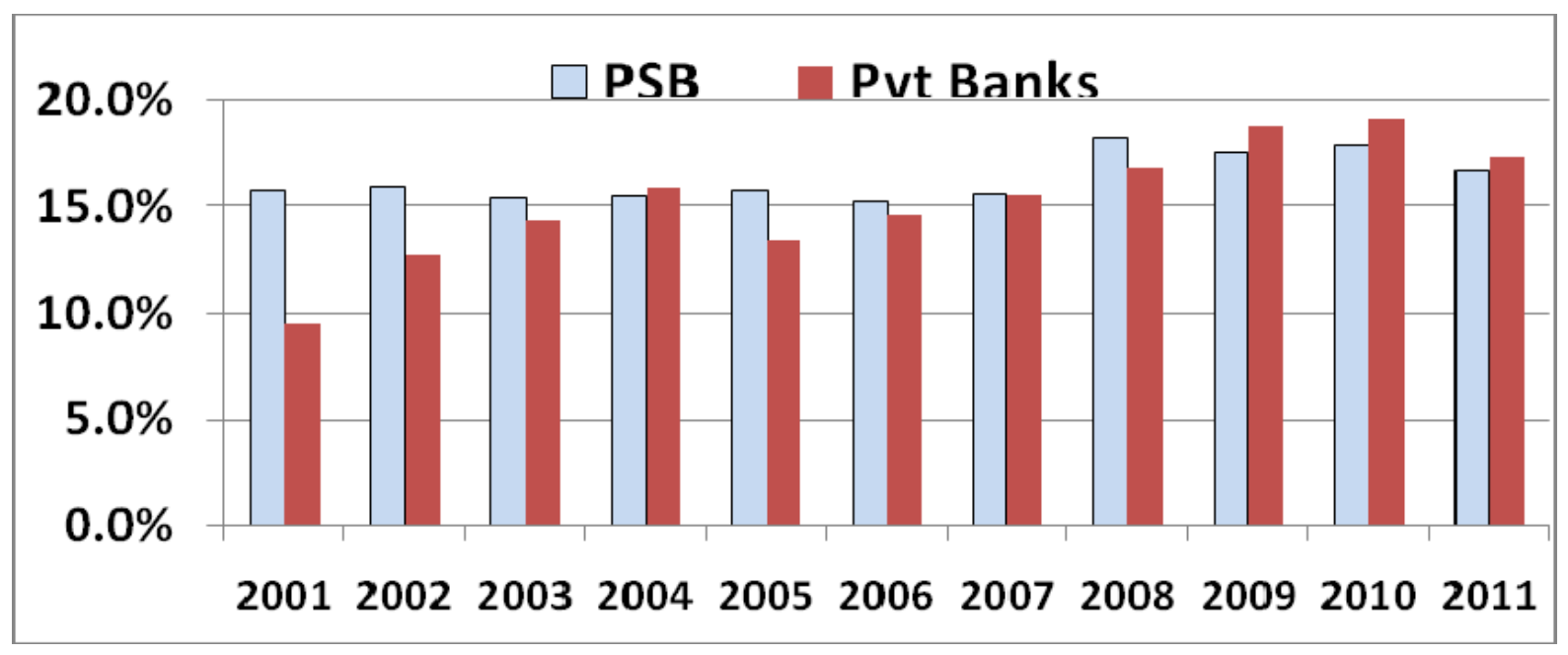

Chart 2: Performance under lending to Total Agriculture* (As percentage of ANBC) 


\subsection{Micro and Small Enterprises}

The limits for investment in plant and machinery/equipment for manufacturing / service enterprise, as notified by Ministry of Micro Small and Medium Enterprises, vide, S.O.1642(E) dated September 29, 2006 are as under:-

\begin{tabular}{|c|c|}
\hline \multicolumn{2}{|c|}{ Manufacturing sector } \\
\hline Enterprises & Investment in plant and machinery \\
\hline Micro Enterprises & Does not exceed`25 lakh \\
\hline Small Enterprises & Is more than ` 25 lakh but does not exceed $` 5$ crore. \\
\hline \multicolumn{2}{|l|}{ Service Sector } \\
\hline Enterprises & Investment in equipment \\
\hline Micro Enterprises & Does not exceed 10 lakh \\
\hline Small Enterprises & Is more than $` 10$ lakh but does not exceed ${ }^{`} 2$ crore. \\
\hline
\end{tabular}

Table 3: Bank loans to medium enterprises (no. of A/c in Lakhs and Amt in Rs. Crores)

Source: RBI

\begin{tabular}{|l|l|l|}
\hline Quarter & \multicolumn{2}{|c|}{ Public Sector Banks } \\
\hline Ended & \multicolumn{1}{|c|}{ No. of A/c } & \multicolumn{1}{c|}{ Amt. O/s } \\
\hline Mar.2011 & 0.46 & 109146 \\
\hline Mar.2012 & 0.68 & 136286 \\
\hline Mar.2013 & 0.77 & 141066 \\
\hline Mar.2014 & 0.46 & 138415 \\
\hline
\end{tabular}

\section{Empirical Analysis}

\subsection{Descriptive Statistics}

Descriptive analysis shows the mean, and standard deviation of the different variables of interest in this study. It also presents the minimum and maximum values of the variables which help in getting a picture about the maximum and minimum values a variable has achieved.

Table 4: Descriptive Statistics

\begin{tabular}{|l|l|l|l|l|l|l|l|l|l|}
\hline & PSL & DEPOSIT & ADVANCES & EMPLOYEE & CAR & ROA & NIM & $\begin{array}{c}\text { C/D } \\
\text { RATIO }\end{array}$ & $\begin{array}{c}\text { NNPA TO } \\
\text { ASSETS }\end{array}$ \\
\hline & & & & & & & & & \\
\hline Mean & 30.37 & 625.40 & 21138.83 & 502062.20 & 13.41 & 0.73 & 2.46 & 75.04 & 3.65 \\
\hline Median & 30.36 & 613.07 & 21443.68 & 483849.50 & 12.90 & 0.90 & 2.40 & 75.15 & 2.68 \\
\hline $\begin{array}{l}\text { Standard } \\
\text { Deviation }\end{array}$ & 1.85 & 229.44 & 8678.07 & 41866.56 & 1.95 & 0.38 & 0.20 & 2.16 & 2.71 \\
\hline Minimum & 28.00 & 342.49 & 8786.41 & 462926.00 & 11.03 & -0.20 & 2.23 & 72.22 & 1.75 \\
\hline Maximum & 34.00 & 1116.64 & 33029.49 & 576124.00 & 17.21 & 1.03 & 2.80 & 77.85 & 10.69 \\
\hline
\end{tabular}

(Source: Excel output) 


\subsection{Correlation}

Table 5: Pearson Bivariate Correlation Coefficients

\begin{tabular}{|c|c|c|c|c|c|c|c|c|c|}
\hline & PSL & DEPOSIT & ADVANCES & $\begin{array}{l}\text { EMPLOYE } \\
\text { TRENGTH }\end{array}$ & CAR & ROA & NIM & $\begin{array}{c}\text { C/D } \\
\text { RATIO }\end{array}$ & $\begin{array}{c}\text { NNPA TO } \\
\text { ASSETS }\end{array}$ \\
\hline PSL & 1.00 & & & & & & & & \\
\hline DEPOSIT & -0.43 & 1.00 & & & & & & & \\
\hline ADVANCES & -0.68 & 0.91 & 1.00 & & & & & & \\
\hline EMPLOYEE & -0.37 & 0.89 & 0.91 & 1.00 & & & & & \\
\hline CAR & 0.05 & 0.74 & 0.55 & 0.72 & 1.00 & & & & \\
\hline ROA & 0.16 & -0.89 & -0.80 & -0.93 & -0.75 & 1.00 & & & \\
\hline NIM & 0.13 & -0.35 & -0.25 & -0.33 & -0.48 & 0.37 & 1.00 & & \\
\hline C/D RATIO & -0.85 & 0.49 & 0.74 & 0.48 & -0.09 & -0.28 & 0.18 & 1.00 & \\
\hline $\begin{array}{ll}\text { NNPA } & \text { TO } \\
\text { ASSETS } & \\
\end{array}$ & -0.06 & 0.88 & 0.72 & 0.88 & 0.78 & -0.98 & -0.37 & 0.18 & 1.00 \\
\hline
\end{tabular}

(Source: Excel output)

\subsection{Regression Analysis}

$$
Y=\beta 0+\beta 1 \times 1+\beta 2 \times 2+\beta 3 \times 3+\beta 4 \times 4+\beta 5 \times 5+\beta 6 \times 6+\beta 7 \times 7+\beta 8 \times 8+\beta 9 \times 9+\beta 4 \times 4 \ldots \ldots+\varepsilon i t
$$

$\mathrm{Y}=$ Dependent variable $=\mathrm{PSL}$

$\beta 0=$ Intercept term

$\beta 1=$ Co-efficient of Deposits

$\beta 2=$ Co-efficient of advances

$\beta 3=$ Co-efficient of Employee strength

$\beta 4=$ Co-efficient of CAR

$\beta 5=$ Co-efficient of ROA

$\beta 6=$ Co-efficient of NIM

$\beta 7=$ Co-efficient of C/D Ratio

$\beta 8=$ Co-efficient of GNPA to Assets Ratio

$\mathrm{x} 1, \mathrm{x} 2, \mathrm{x} 3, \mathrm{X} 4 \ldots \ldots=$ Independent variables

\subsection{Result}

\begin{tabular}{|l|l|}
\hline \multicolumn{2}{|c|}{ SUMMARY OUTPUT } \\
\hline \multicolumn{2}{|c|}{ Regression Statistics } \\
\hline \multicolumn{2}{|c|}{} \\
\hline Multiple R & 0.99 \\
\hline R Square & 0.98 \\
\hline Adjusted R Square & 0.79 \\
\hline Standard Error & 0.86 \\
\hline Observations & 10.00 \\
\hline
\end{tabular}




\begin{tabular}{|c|c|c|c|c|}
\hline & Coefficients & $\begin{array}{l}\text { Standard } \\
\text { Error } \\
\end{array}$ & $t$ Stat & $P$-value \\
\hline Intercept & -1.8890 & 45.6198 & -0.0414 & 0.9737 \\
\hline DEPOSIT & 0.0189 & 0.0166 & 1.1402 & 0.4584 \\
\hline ADVANCES & -0.0010 & 0.0006 & -1.8299 & 0.3184 \\
\hline $\begin{array}{l}\text { EMPLOYEE } \\
\text { STRENGTH }\end{array}$ & 0.0001 & 0.0001 & 1.0389 & 0.4879 \\
\hline CAR & 0.2323 & 0.5223 & 0.4447 & 0.7336 \\
\hline ROA & -19.8432 & 15.1663 & -1.3084 & 0.4155 \\
\hline NIM & 1.9827 & 1.8857 & 1.0514 & 0.4840 \\
\hline C/D RATIO & 0.4079 & 0.6833 & 0.5970 & 0.6573 \\
\hline $\begin{array}{|ll|}\text { NNPA } & \text { TO } \\
\text { ASSETS } & \\
\end{array}$ & -2.7577 & 2.4040 & -1.1471 & 0.4564 \\
\hline
\end{tabular}

\begin{tabular}{|l|l|l|l|l|l|}
\hline \multicolumn{1}{|c|}{$\boldsymbol{d}$} & \multicolumn{1}{c|}{$\boldsymbol{S} \boldsymbol{S}$} & \multicolumn{1}{c|}{$\boldsymbol{M S}$} & \multicolumn{1}{c|}{$\boldsymbol{F}$} & Significance $\boldsymbol{F}$ \\
\hline Regression & 8 & 30.01 & 3.75 & 5.11 & 0.33 \\
\hline Residual & 1 & 0.73 & 0.73 & & \\
\hline Total & 9 & 30.74 & & & \\
\hline
\end{tabular}

\subsection{Equation}

PSL $=-1.8890+0.0189 *$ DEPOSIT $+-0.0010 *$ ADVANCES $+0.0001 *$ EMPLOYEE STRENGTH $+0.2323 *$ CAR $+-19.8432 * \mathrm{ROA}+1.9827 * \mathrm{NIM}+0.4079 * \mathrm{C} / \mathrm{D}$ RATIO + $2.7577 *$ NNPA TO ASSETS + عit

$\mathbf{R}^{2}$ of 0.98 implies that the eight independent variables are collectively able to explain $98 \%$ Variation in PSL.

F-statistic of 5.11 and Sig. (F-Statistic) value of 0.33 shows that the model has statistically significant explanatory power.

Intercept value of -1.8890 is the value of ratio of Total PSL of a company on an average when values of all independent variables are equal to 0 .

\subsection{Test of Hypothesis}

\section{- PSL and Bank Size}

Bank size consists of Deposits, advances and employee strength. From this result it is observed that Deposits positively affects PSL. But the impact is insignificant. ( P-Value is 0.4584 ).

Similarly Advances shows a negative relationship and Employee strength shows a positive but a very low impact with Priority sector lending. So overall we can say there is a positive relationship (although it is not significant) between bank size and PSL. That indicates if the bank size increases lending to Priority sector will also increase and vice versa. So H1 is accepted. 


\section{- PSL and Bank Performance}

Bank performance consists of CAR, ROA and NIM. From this result it is found that CAR positively affects PSL. But the impact is insignificant.

Similarly ROA shows a negative relationship and NIM shows a positive but insignificant with Priority sector lending. So overall we can say that here also is a positive relationship (although it is not significant) between bank performance and PSL. That indicates if the bank performance increases lending to Priority sector will also increase and vice versa. So H1 is accepted.

\section{- PSL and Lending Efficiency}

Lending efficiency consists of C/D Ratio and GNPA to Assets Ratio. From this result it is found that C/D Ratio positively affects PSL. But the impact is insignificant.

Similarly GNPA shows a negative relationship but insignificant with Priority sector lending. So overall we can say that here also is a Negative relationship (although it is not significant) between lending efficiency and PSL. That indicates if the Gross NPA Ratio decreases lending to priority sector increases or vice versa. So $\mathbf{H 1}$ is rejected.

\section{Major Findings}

The findings of the study suggest that banks in general, have complied with the total PSL targets, with private sector banks performing better in this regard. However, they all have been unable to comply with the sectoral targets for agriculture and weaker section lending, with public sector banks being slightly better in this regard. Bank size and bank performance show a positive relationship with Priority sector lending where as lending efficiency of banks depicts a negative relationship with PSL. And the whole relationship was not significant.

\section{Policy Recommendations}

Based on the findings from the study, a number of policy recommendations can be made for improving the effectiveness of PSL program. Some of the important suggestions which emerge from the findings are as follows. In view of the significance of bank size and nature of ownership in PSL, it may be worthwhile considering the idea of establishing public sector banks sponsored smaller-sized, separate entities, which are privately managed, for lending to priority areas within the PSL program. Similar suggestion has also been made in a few earlier studies (Berger, Miller, Petersen, Rajan and Stein, 2005). Lending to small and rural borrowers in PSL is more aligned for relationship lending. This requires flexibility in organization structures and policies to cater to the peculiar nature of PSL, where public sector banks may not have a comparative advantage. Smaller, private and distinct entities may be equipped to have greater flexibility in this regard. They may also be able to distance themselves from political interventions. Therefore, separate entities of banks (especially of public sector banks) may be established for PSL, to better serve its objectives. Further, while considering proposals for consolidation in Indian banking industry, the adverse impact of bank size on PSL may also be considered by the government (Peek and Rosengren 1995). In view of the significance of lending efficiency in determining PSL patterns, it is important to reorient the human The resource (HR) policies to make them favourable for PSL. Such redesigning of HR policies which takes into account the special characteristics of PSL can be undertaken by the private sector banks on their own. However, for public sector banks (which constitute a major part of the banking system in most developing countries), this may 
require initiative/ approval of the government. It may be emphasized that there is an urgent need to redesign HR policies to ensure higher PSL.

\section{Conclusion}

The scope and extent of priority sector lending has undergone a significant change in the postreform period with several new areas and sectors being brought under its purview. A drastic change in the priority sector lending seem to have happened with the setting up of an Internal Working Group under the chairmanship of shri.C.S.Murthy by RBI to examine the need for continuance of priority sector lending prescriptions, review the existing policy, 130 targets and sub-targets and to recommend changes, required in this regard. The lending activity towards priority sector by the entire selected research units are following the norms for advances to priority sector on an average nearer one fourth to one third of their total advances during the research period. It is suggested that bank have to increase their lending activity towards priority sector to boost up the economy as priority sector is the key segment of the development of the country.

\section{References}

[1] Report On Trend And Progress Of Banking In India 2009-10, Rbi.

[2] Master Circular - Prudential Norms On Income Recognition, Asset Classification And Provisioning Pertaining To Advances, 2008.

[3] Master Circular - Disclosure In Financial Statements - 'Notes To Accounts', 2014.

[4] Master Circular- Credit Facilities To Minority Communities, 2014

[5] Master Circular - Credit Facilities To Scheduled Castes (Scs) \& Scheduled Tribes (Sts)

[6] Ahmed, J. (2010) "Priority sector lending by Commercial Banks in India: A Case of Barak Valley," Asian Journal of Finance \& Accounting, vol. 2(1), p. 92-110. An Approach to twelfth five-year plan (2012-17) "Faster, Sustainable and More Inclusive Growth," Planning Commission, Government of India, October 2011.

[7] Banerjee, A. V., \& Duflo, E. (2014) "Do firms want to borrow more? Testing credit constraints using a directed lending program," The Review of Economic Studies, vol. 81(2), p. 572-607.

[8] Banerjee, A., \& Duflo, E. (2004) "What do banks (not) do?" Economic and Political Weekly, p.4212- 4213.

[9] Banerjee, A.V., Cole, S., \& Duflo, E. (2003) "Bank Financing in India," MIT, Department of Economics, Working Paper Series, October.

[10] Calomiris, C.W., \& Himmelberg, C.P. (1993) "Directed Credit Programs for Agriculture and Industry Arguments from Theory and Fact," Proceedings of the World Bank Annual Conference on Development Economics. Cole R.A., Goldberg L.,

[11] White L., (2004) "Cookie Cutter vs. Character: The Micro Structure of Small Business Lending by Large and Small Banks," Journal of financial and quantitative analysis, vol. 39(2), June, p. 227-251.

[12] Kohli, R. (1997)"Directed Credit and Financial reform," Economic and Political Weekly, vol. 32(42), October, p. 2667-2676.

[13] Kolari, J.; Berney, R.; and Ou, C. (1996) "Small Business Lending and Bank Profitability," Journal of Entrepreneurial and Small Business Finance, vol. 5(1), p. 1-15.

[14] Kumar A., Francisco M. (2005) "Enterprise Size, Financing patterns, and credit constraints in Brazil. Analysis of Data from the Investment Climate Assessment Survey," World Bank Publications, vol. 6. 
[15] Llanto, G. M., Geron, P., \& Tang, C. (1999) "Directed credit programs; issues and framework for reform," Manila, October.

[16] Favara, G (2003) : 'An Empirical Reassessment of Relationship between Finance and Growth', IMF Working Paper No WP/03/123, International Monetary Fund, Washington.

[17] GoI (1991): "Report of the Committee on the Financial System", chairman M.Narasimham, ministry of finance, Government of India, New Delhi.

[18] GoI (2004) : Economic Survey, 2003-04, Ministry of Finance, Government of India, New Delhi.

[19] Gopinath, Shyamala (2005) : 'Retail Bankng : Opportunities and Challenges', Lecture Delivered at IBA - Banking Frontiers International Conference, May 28, Mumbai.

[20] Gopinath, Shyamala (2005) : 'Retail Bankng : Opportunities and Challenges', Lecture Delivered at IBA - Banking Frontiers International Conference, May 28, Mumbai.

[21] International Monetary Fund (2004) : 'Are Credit Booms in Emerging Markets a Concern?' World Economic Outlook, April, Chapter IV.

[22] Jaitly,Jaya (1997): 'Organising the Unorganised in Kerala', Economic and Political Weekly, July 12.

[23] Joshi,PN (2005): Needed- A National Banking Policy, Economic and Political Weekly, July 9.

*Corresponding author.

E-mail address: gpanda673@ gmail.com 